\title{
Antimicrobial activities of silver nanoparticles synthesized from Lycopersicon esculentum extract
}

\author{
Swarnali Maiti', Deepak Krishnan², Gadadhar Barman', Sudip Kumar Ghosh² and Jayasree Konar Laha*
}

\begin{abstract}
Background: It has been known for quite some time now that silver nanoparticles (AgNP) can inhibit microbial growth and even kill microbes. Our investigation reports the antimicrobial activity of AgNP against a model bacterium, Escherichia coli.

Methods: The aqueous extract of Lycopersicon esculentum (red tomato) was used for the rapid synthesis of AgNP, which is very simple and eco-friendly in nature. The UV-visible spectroscopy technique was employed to establish the formation of AgNP.

Results: The transmission electron microscopic images showed that the particles were of mostly spherical shape. For the bacteriological tests, the microorganism E. coli was inoculated on Luria broth (LB) agar plate in the presence of varied amounts of AgNP. The antibacterial activity was obvious from the zone of inhibition. At concentration 20 $\mu \mathrm{g} / \mathrm{ml}$ and above, the AgNP showed a clear zone of inhibition and the minimum inhibitory concentration of AgNP to E. coli was $50 \mu \mathrm{g} / \mathrm{ml}$. Growth rates and bacterial concentrations were determined by measuring optical density at $600 \mathrm{~nm}$ at different time points.

Conclusions: From the slope of the bacterial growth curve, it has been concluded that the nanoparticles are bacteriostatic at low concentration and bactericidal at high concentration. So these nanoparticles are believed to act as preventive for bacterial contamination.
\end{abstract}

Keywords: Silver nanoparticle; Green synthesis; Lycopersicon esculentum; Antibacterial activity; Escherichia coli

\section{Background}

Disease-causing microbes that have become resistant to drug therapy are an increasing public health problem. Many researchers are now engaged in developing new effective antimicrobial reagents with the emergence and increase of microbial organisms resistant to multiple antibiotics, which will increase the cost of health care. Therefore, there is an urgent need to develop new bactericides. Silver has been used for years in the medical field for antimicrobial applications such as burn treatment (Parikh et al. 2005; Ulkur et al 2005), elimination of microorganisms on textile fabrics (Jeong et al. 2005; Lee et al. 2007; Yuranova et al. 2003), disinfection in water treatment (Russell and Hugo 1994; Chou et al. 2005), prevention of bacteria colonization on catheters (Samuel and Guggenbichler 2004; Alt et al. 2004; Rupp et al. 2004), etc. It has also been found to prevent HIV from binding to host cells (Sun et al. 2005), but the effects of silver nanoparticles (AgNP) on microorganisms have not been developed fully. Nanosilver, being less reactive than silver ions, is expected to be more suitable for medical applications. Reducing the particle size of metals is also an efficient and reliable tool for improving their biocompatibility, which facilitates their applications in different fields such as bioscience and medicine. The mechanism of the bacterial effect of AgNP as proposed is due to the attachment of AgNP to the surface of the cell membrane, thus disrupting permeability and respiration functions of the cell (Kevitec et al. 2008). It is also proposed that AgNP not only interact with the surface of a membrane but can also penetrate inside the bacteria (Morones et al. 2005). The antibacterial activity of AgNP is significantly enhanced when it is modified with sodium dodecyl sulfate (SDS) (Kevitec et al. 2005; Carpenter 1972).

\footnotetext{
* Correspondence: j.laha@yahoo.co.in

${ }^{1}$ Midnapore College, Midnapore, West Bengal, India

Full list of author information is available at the end of the article
}

\section{实 Springer}

(C) 2014 Maiti et al.; licensee Springer. This is an Open Access article distributed under the terms of the Creative Commons Attribution License (http://creativecommons.org/licenses/by/4.0), which permits unrestricted use, distribution, and reproduction in any medium, provided the original work is properly cited. 
In this study, we have investigated the antimicrobial effects of silver nanoparticles prepared by a biosynthesis method. The chemical reduction method is widely used to synthesize AgNP because AgNP could be synthesized under a mild as well as on a large scale (Cao et al. 2010). However, the use of environmentally benign materials like plant leaf extract, bacteria, and fungi for the synthesis of silver nanoparticles is more acceptable as they offer several benefits over chemical methods like conditions of high temperature, pressure, and toxic chemicals which are not required in the synthesis protocol (Singh et al. 2010). Therefore, preparation of AgNP by a green synthesis approach has compatibility for pharmaceutical and biomedical applications.

In the present work, the synthesis of silver nanoparticles has been carried out using the aqueous extract of Lycopersicon esculentum (red tomato). The water extract of tomato juice mostly contains proteins and watersoluble organic acids (Gould 1983) which are believed to act as stabilizing and reducing agents, respectively. With these nanoparticles, a preliminary test for antibacterial activity was carried out by cup diffusion method and the effects of AgNP on bacterial growth has been studied by employing minimum inhibitory concentration (MIC) method. Results obtained by us prove that AgNP prepared by the green method is suitable for the formulation of new types of bactericidal materials.

\section{Results and discussion Results}

\section{Characterization and optimization of AgNP preparation}

The absorbance spectra of the AgNP were analyzed by using a 'SHIMADZU' UV 1800 spectrophotometer (Shimadzu Corporation, Kyoto, Japan). AgNP exhibited a reddish yellow color in water due to the excitation of the localized surface plasmon vibrations of the metal nanoparticles. Generally, the surface plasmon resonance (SPR) bands are influenced by the size, shape, morphology, composition, and dielectric environment of the synthesized nanoparticles (Kelly et al. 2003; Stepanov 1997). Previous studies showed that spherical AgNP contribute to the absorption bands at around 400 $\mathrm{nm}$ in the UV-visible spectra (Maiti et al. 2013; Barman et al. 2014). The SPR band due to AgNP was observed in our case at around $410 \mathrm{~nm}$ (Figure 1) when $3 \times 10^{-3} \mathrm{M}$ silver nitrate solution was used. This strongly suggested that AgNP were nearly spherical in shape and it was confirmed by the transmission electron microscopy (TEM) results.

In this study, AgNP have been synthesized both in the presence and in the absence of a stabilizer and both anionic and neutral surfactants were used one at a time. Though soluble proteins and amino acids present in L. esculentum extract were expected to act as stabilizer for nanoparticles (Barman et al. 2013), a smooth and narrow absorption band of AgNP at $410 \mathrm{~nm}$ was observed only in the presence of SDS of $3 \times 10^{-3} \mathrm{M}$ (Figure 1A). So we preferred to synthesize AgNP using SDS as the stabilizing agent.

An absorption band was observed at $410 \mathrm{~nm}$ for 1:1 extract composition. The plasmon band shifted to higher values with the increase of the concentrations of tomato in aqueous extracts and reached to $415 \mathrm{~nm}$ for 3:2 composition (Figure 1B). At concentrations higher than 3:2 composition, the plasmon band shifted to higher values and the extinction coefficient of the band decreased appreciably. However, tomato extract of 1:1 composition was used throughout the work.

A bathochromic shift of the SPR bands from 388 to 445 $\mathrm{nm}$ was observed while the concentration of $\mathrm{AgNO}_{3}$ varied from $3 \times 10^{-3}$ to $5 \times 10^{-2} \mathrm{M}$ keeping the extract composition constant at 1:1 using SDS of $3 \times 10^{-3} \mathrm{M}$ (Figure $1 \mathrm{C}$ ). When the particle size increased, the absorption peak shifted towards the red wavelength, which indicated the formation of larger sized nanoparticles (Peng et al. 2010).

The shape and size distribution of the synthesized AgNP were characterized by TEM study. The TEM images were taken using JEOL JEM-2100 high-resolution transmission electron microscope (HR-TEM; JEOL Ltd., Akishima-shi, Japan). Samples for the TEM studies were prepared by placing a drop of the aqueous suspension of particles on carbon-coated copper grids followed by solvent evaporation under vacuum. The TEM images of AgNP produced from 1:1 composition of tomato extract showed that the particles were mostly spherical and their sizes varied from 10 to $40 \mathrm{~nm}$. Selected area electron diffraction (SAED) pattern illustrated the crystalline nature of AgNP (Figure 2).

\section{Antibacterial activity of AgNP against the microorganism}

Preliminary test for antibacterial activity The antimicrobial activity of AgNP was evaluated against Escherichia coli by cup diffusion method. Approximately $10^{6}$ colony-forming units (CFU) of the microorganism E. coli were inoculated on Luria broth (LB) agar plate, and then different concentrations of $\operatorname{AgNP}(1,2,5,10,20,50,100$, and $200 \mu \mathrm{g} / \mathrm{ml}$ ) were added to the well present in the LB agar plate. A reaction mixture containing no AgNP was put in the well in the LB plate and cultured under the same condition as the control test. All the LB plates were incubated at $37^{\circ} \mathrm{C}$ overnight. After incubation, the plates were observed for the presence of a zone of inhibition. The antibacterial activity of AgNP was proved from the zone of inhibition (Figure 3). At concentration $20 \mu \mathrm{g} / \mathrm{ml}$ and above, the AgNP showed a clear zone of inhibition. No zone of inhibition was found in the vehicle control well (spot in the middle of the plate) which suggested that the antimicrobial activity was specifically due to AgNP. 


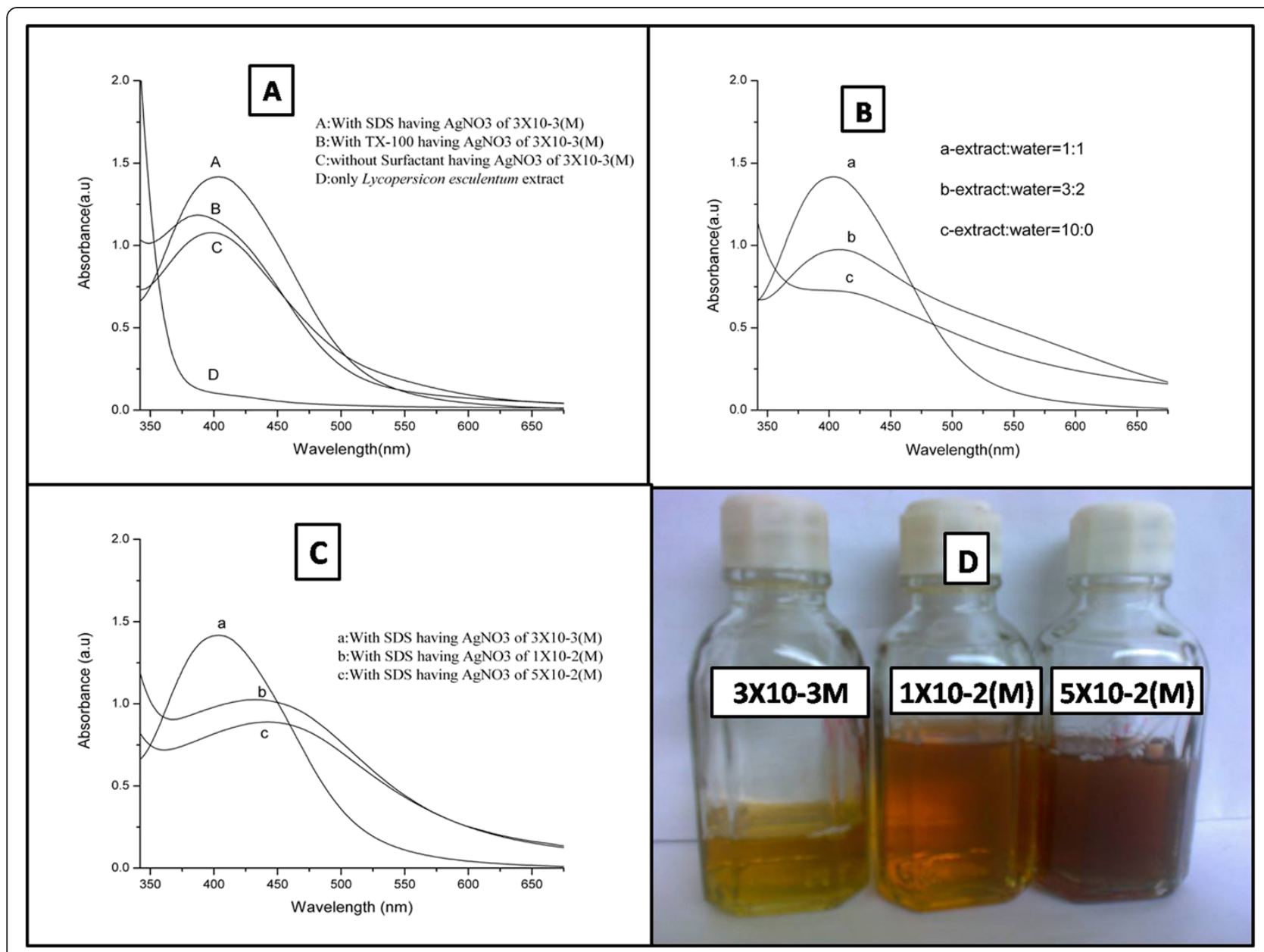

Figure 1 UV-Vis spectra and digital photographic images of AgNP. (A) UV-Vis spectra of AgNP: spectrum 1A-A with surfactant SDS, spectrum 1A-B with surfactant TX-100, spectrum 1A-C without any surfactant, and spectrum 1A-D is for pure Lycopersicon esculentum extract. (B) UV-Vis spectra of AgNP at different compositions of Lycopersicon esculentum extract. (C) UV-Vis spectra of AgNP with varying concentrations of silver nitrate (a) at $3 \times 10^{-3} \mathrm{M}$, (b) at $1 \times 10^{-2} \mathrm{M}$, and (c) at $5 \times 10^{-2} \mathrm{M}$ using 1:1 extract composition and $3 \times 10^{-3} \mathrm{M}$ SDS solution in each case. (D) Digital photographic images of AgNP produced from different concentrations of silver nitrate.

Evaluation of antibacterial effectiveness using minimum inhibitory concentration method The antimicrobial activity of AgNP was evaluated using the MIC method. The antimicrobial effectiveness was determined against the bacterial concentration of $10^{6} \mathrm{CFU} / \mathrm{ml}$ with different

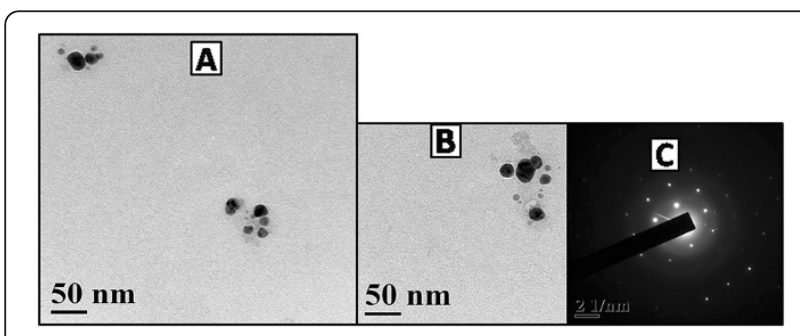

Figure 2 TEM micrographs and SAED pattern of AgNP. TEM micrographs of AgNP synthesized from Lycopersicon esculentum extract (A, B). SAED pattern of AgNP synthesized from Lycopersicon esculentum extract (C). concentrations of AgNP (0.2, 0.5, 1, 2, 5, 10, 20, 50, and $100 \mu \mathrm{g} / \mathrm{ml})$. The cultures were incubated at $37^{\circ} \mathrm{C}$ at $250 \mathrm{rpm}$. Bacterial concentrations were determined by measuring optical density (OD) at $600 \mathrm{~nm}(0.1$ OD600 corresponding to $10^{8}$ cells per milliliter). With the increase of concentration of nanoparticles, the final bacterial concentration decreased. When the concentration of AgNP was $50 \mu \mathrm{g} / \mathrm{ml}$, growth of $E$. coli was completely inhibited, which indicated that the MIC of AgNP to E. coli was $50 \mu \mathrm{g} / \mathrm{ml}$ (Figure 4).

Effect of AgNP on bacterial growth To determine the growth curve in the presence of silver nanoparticles, E. coli bacteria were grown in liquid LB medium till they reached the log phase. Then they were diluted in fresh LB liquid medium to optical density (OD600) 0.05, 0.1, and 0.2. AgNP solution was added into the cell culture medium at different concentrations, and the culture was 


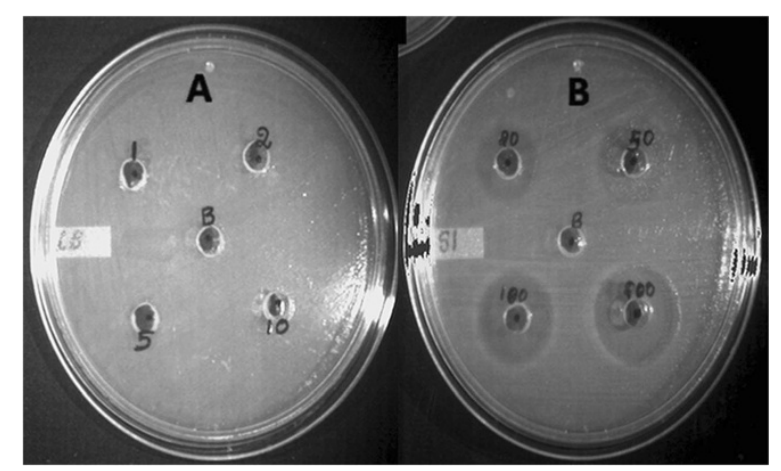

Figure 3 Antibacterial activity of AgNP. Antibacterial activity of AgNP having different concentrations: (A) 1, 2, 5, and $10 \mu \mathrm{g} / \mathrm{ml}$ and (B) $20,50,100$, and $200 \mu \mathrm{g} / \mathrm{ml}$, with $10^{6}$ CFU of E. coli inoculated on Luria broth agar plate. The ' $\mathrm{B}$ ' spot in the middle of the agar plate is for the blank test, having no AgNP.

incubated at $37^{\circ} \mathrm{C}$ and $250 \mathrm{rpm}$. Growth rates and bacterial concentrations were determined by measuring $\mathrm{OD}$ at $600 \mathrm{~nm}$ at different time points (Figure 5A,B,C).

The slope of the bacterial growth curve continuously decreased with increasing nanoparticle concentration. This means that at low concentration of nanoparticles, the growth of bacteria was delayed and at higher concentration, growth was completely inhibited. So it can be concluded that the nanoparticles are bacteriostatic at low concentration and bactericidal at high concentration. It was also clear from the graphs that the bacterial growth was dependent on the initial number of cells present in the medium. It was observed that at lower initial OD, the
AgNP concentration necessary to completely inhibit bacterial growth was also low. So silver nanoparticles produced by us will be suitable for preventing bacterial contamination.

\section{Discussion}

Chemical antimicrobial agents are increasingly becoming resistant to a wide spectrum of antibiotics. An alternative way to overcome the drug resistance of various microorganisms is therefore urgently needed. Ag ions and silver salts have been used for decades (Silver and Phung 1996) as antimicrobial agents in various fields due to their growthinhibitory abilities against microorganisms. However, there are some limitations in using $\mathrm{Ag}$ ions or Ag salts as antimicrobial agents. Probable reasons include the interfering effects of salts. This type of limitation can be removed by using silver in nano form. Due to the increase of the surface area in nano state, the contact area between $\operatorname{Ag}(0)$ and that of the microorganism increases. To use AgNP against microbes in various fields, it is important and necessary to prepare AgNP in a green environment. In this study, we report a green method for the preparation of AgNP which is environmentally benign and cost-effective.

For the assessment of the antimicrobial effects of AgNP, $E$. coli was used in our study. The effect was investigated by growing $E$. coli on agar plates and in liquid LB medium, supplemented with AgNP. The bacterial growth was completely inhibited in the presence of AgNP on the LB agar plate. The inhibition solely depended upon the AgNP concentration. It showed a clear zone of inhibition at and above the concentration $20 \mu \mathrm{g} / \mathrm{ml}$.

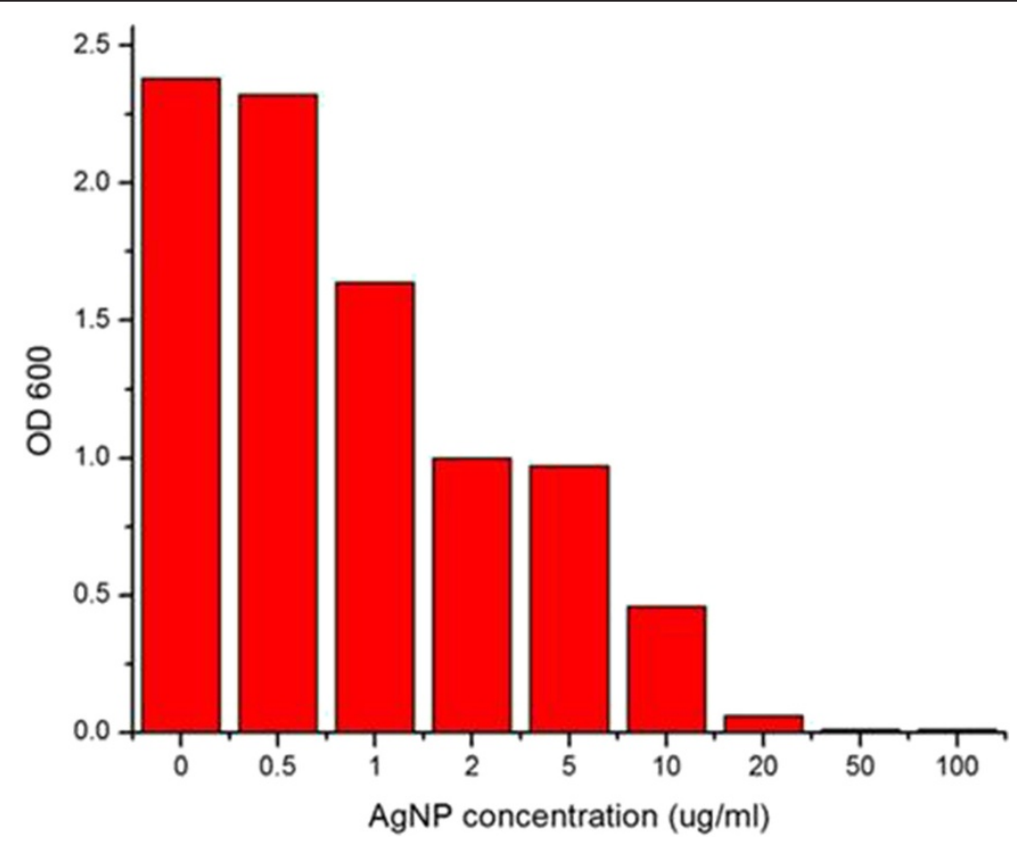

Figure 4 Optical density vs concentration of AgNP. MIC assay $50 \mu \mathrm{g} / \mathrm{ml}$. 


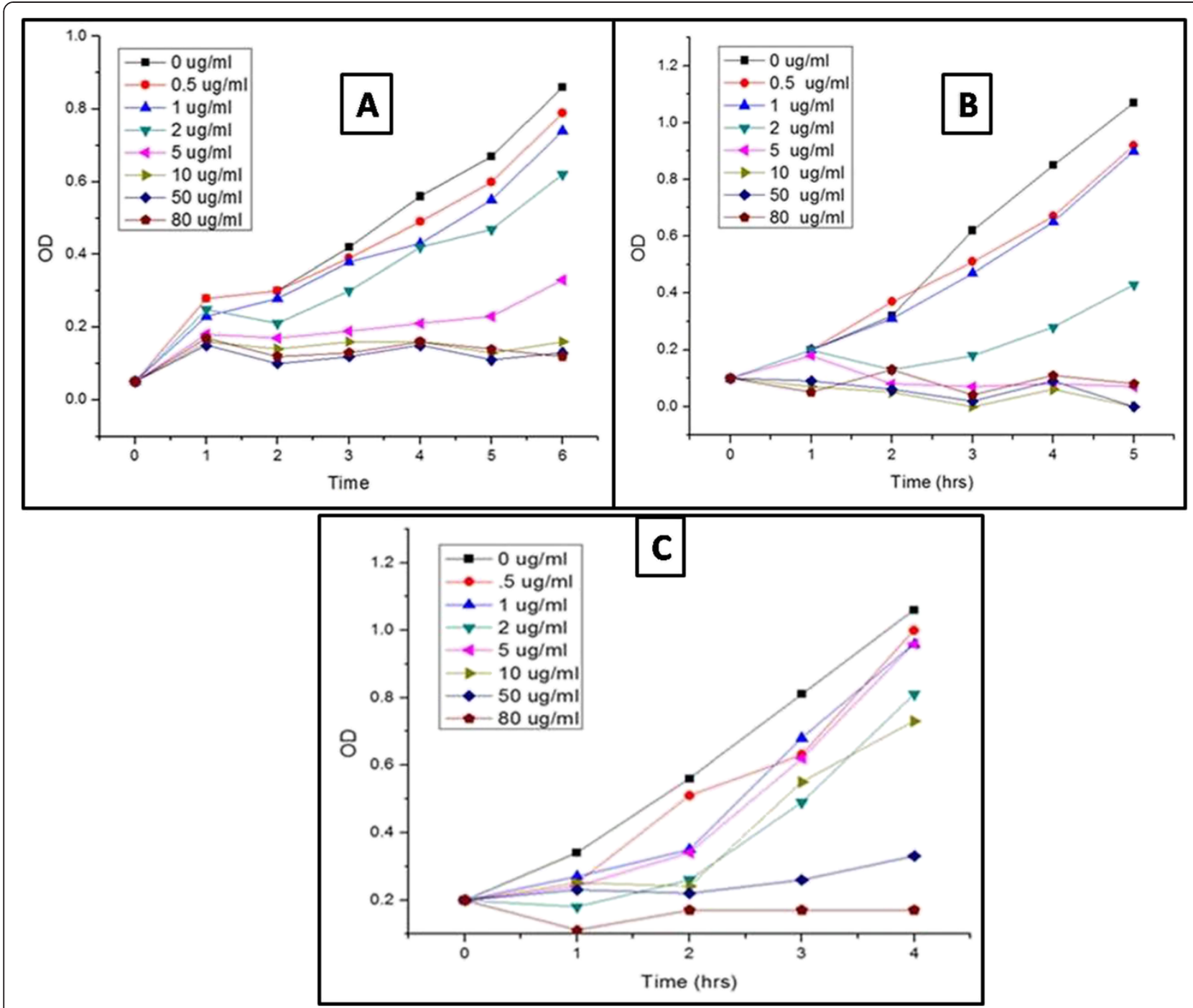

Figure 5 Growth curves with initial OD 0.05 (A), 0.10 (B), and 0.20 (C).

To study the antimicrobial effectiveness of AgNP, we treated a bacterial concentration at high CFU $\left(10^{6} / \mathrm{ml}\right)$ with varying concentrations of AgNP from 0.2 to 100 $\mu \mathrm{g} / \mathrm{ml}$. When the concentration of AgNP was increased, the bacterial concentration was found to decrease. At concentration $50 \mu \mathrm{g} / \mathrm{ml}$ of AgNP, the growth of E. coli was completely inhibited, which indicated that the minimum inhibitory concentration was $50 \mu \mathrm{g} / \mathrm{ml}$ (Figure 4). Since high CFU are seldom found in real-life systems, it may be concluded that these AgNP have a biocidal effect and effectiveness in delaying bacterial growth, findings which may lead to valuable inventions in the future in various fields like in antimicrobial systems as well as medical devices.

The slope of the bacterial growth curves (Figure 5A,B,C) continuously decreased with increasing nanoparticle concentration. This indicated that at low concentration of nanoparticles, bacterial growth was delayed and growth was completely inhibited at higher concentrations. So it appears that these particles are bacteriostatic at low concentration and bactericidal at high concentration. It is also clear from the graphs that the bacterial growth is dependent on the initial number of cells present in the medium. It was observed that at lower initial OD, the AgNP concentration necessary to completely inhibit bacterial growth was also low. So it is confirmed that these nanoparticles may be used to prevent bacterial contamination.

The mechanism of the inhibitory effects of Ag ions on microorganisms is partially known. It is reported that the positive charge on the silver ion is the reason for antimicrobial activity as it can attract the negatively charged cell membrane of microorganisms through the electrostatic interaction (Dibrov et al. 2002; Hamouda et al. 2000). Due to their unique size and greater surface 
area, silver nanoparticles can easily reach the nuclear content of bacteria (Chen et al. 2010; Chudasama et al. 2009). A survey of the literature showed that the electrostatic attraction between negatively charged bacterial cells and positively charged nanoparticles was crucial for the antibacterial activity (Stoimenov et al. 2000). The AgNP used in this study, however, received negative charge from SDS, an anionic surfactant, used during synthesis. The bacterium $E$. coli being gram-negative, the interaction with the negatively charged nanoparticles might have occurred through 'pit' formation in the cell wall of the bacteria (Sondi and Salopek-Sondi 2004) which helped the permeability and resulted in cell death.

\section{Experimental Materials}

Silver nitrate and SDS, both of AR grade, were purchased from Sigma-Aldrich Chemical Ltd. (St Louis, MO, USA) Sodium hydroxide was purchased from Merck (Darmstadt, Germany). Double-distilled de-ionized water was used in all experiments.

\section{Green synthesis of silver nanoparticles by L. esculentum extract}

Silver nanoparticles were made according to the recipe described below. For this purpose, red tomato (L. esculentum) was collected from the local market and washed with double-distilled de-ionized water. The tomato skin was removed and the whole mass was squeezed to get tomato juice. Then it was diluted two times and filtered using a Whatman filter paper to get the aqueous extract of the red tomato.

\section{Method}

AgNP were produced by reduction of silver nitrate solution by using red tomato extract. Ten milliliters of aqueous red tomato extract was mixed with $10 \mathrm{ml}$ of $3 \times 10^{-3}$ M SDS solution and cooled in ice-cold water for few minutes. The solution was made alkaline ( $\mathrm{pH} 9)$ with $0.15 \mathrm{~N}$ sodium hydroxide solution. After that, $8 \mathrm{ml}$ of $3 \times 10^{-3} \mathrm{M}$ aqueous silver nitrate was added into it dropwise with continuous stirring. The mixture was then heated for 20 $\min$ at $80^{\circ} \mathrm{C}$. The color of the solution gradually changed from colorless to reddish yellow. The reddish yellow color indicated the formation of AgNP.

\section{Conclusions}

We have described a simple and green method for the synthesis of AgNP by using the aqueous extract of red tomato. The formation of AgNP was confirmed by UV-visible spectroscopy. The TEM images showed that the particles were mostly spherical. These biosynthesized AgNP were then used to demonstrate antimicrobial activity against a model bacterium, E. coli. The antibacterial activity of AgNP was apparent from the zone of inhibition. At concentrations 20 $\mu \mathrm{g} / \mathrm{ml}$ and above, the AgNP showed a clear zone of inhibition and the MIC of AgNP to E. coli was $50 \mu \mathrm{g} / \mathrm{ml}$. Growth rates and bacterial concentrations were determined by measuring $\mathrm{OD}$ at $600 \mathrm{~nm}$ at different time points. From the slope of the bacterial growth curve, it has been concluded that the nanoparticles are bacteriostatic at low concentration and bactericidal at high concentration. So these nanoparticles are believed to act as preventive for bacterial contamination.

\section{Competing interests}

The authors declare that they have no competing interests.

\section{Authors' contributions}

SM and DK carried out the experiments. SM, GB, and DK drafted the manuscript. JKL and SKG guided the research and modified the manuscript. All authors read and approved the final manuscript.

\section{Acknowledgements}

We are thankful to Central Research Facility at IIT Kharagpur, India, for the HR-TEM measurements.

\section{Author details}

${ }^{1}$ Midnapore College, Midnapore, West Bengal, India. ${ }^{2}$ Department of

Biotechnology, Indian Institute of Technology, Kharagpur, India.

Received: 26 July 2014 Accepted: 21 October 2014

Published online: 13 November 2014

\section{References}

Alt V, Bechert T, Streinrucke P, Wagener M, Seidel P, Dingeldein E, Domanne E, Schnettler R (2004) An in vitro assessment of the antibacterial properties and cytotoxicity of nanoparticulate silver bone cement. Biomaterials 25:4383-4391

Barman G, Maiti S, Konar LJ (2013) Bio-fabrication of gold nanoparticles using aqueous extract of red tomato and its use as a colorimetric sensor. Nanoscale Res Lett 8:181-189

Barman G, Samanta A, Maiti S, Konar $\sqcup$ (2014) Detection of $\mathrm{Cu}^{+2}$ ion by the synthesis of bio-mass-silver nanoparticle nanocomposite. Int J Scientific and Engg Res 5(6):1086-1097

Cao XL, Cheng C, Ma YL, Zhao CS (2010) Preparation of silver nanoparticles with antimicrobial activities and the researches of their biocompatibilities. J Mate Sci Mater M 21:2861-2868

Carpenter PL (1972) Microbiology. W.B. Saunders Company, Philadelphia, p 245

Chou WL, Yu DG, Yang MC (2005) The preparation and characterization of silver-loading cellulose acetate hollow fibre membrane for water treatment. Polym Adv Technol 16:600-607

Chen SF, Li JP, Quin K, Xu WP (2010) Large scale photochemical synthesis of $\mathrm{M} @ T i O_{2}$ nanocomposites $(\mathrm{M}=\mathrm{Ag}, \mathrm{Pd}, \mathrm{Au}, \mathrm{Pt})$ and their optical properties, Co oxidation performance and antibacterial effect. Nano Res 3:244-255

Chudasama B, Vala AV, Andharya N, Upadhyay RV, Mehta RV (2009) Enhanced antibacterial activity of bifunctional $\mathrm{Fe}_{3} \mathrm{O}_{4}$ core-shell nanostructures. Nano Res 2:955-965

Dibrov P, Dzoiba J, Gosink KK, Häse CC (2002) Chemiosmotic mechanism of antimicrobial activity of $\mathrm{Ag}(+)$ in vibrio cholera. Antimicrob Agents Chemother 46:2668-2770

Gould WA (1983) Tomato production, processing and quality evaluation, 2nd edition. AVI Publishing Company, Inc, Westport, CT

Hamouda T, Myc A, Donovan B, Shih A, Reuter JD, Baker RJ (2000) A novel surfactant nanoemulsion with a unique non-irritant topical antimicrobial against bacteria, enveloped viruses and fungi. Microbial Res 156:1

Jeong SH, Yeo SY, Yi SC (2005) The effect of filler particle size on the antibacterial properties of compounded polymer/silver fibres. J Mater Sci 40:5407-5411

Kelly KL, Coronado E, Zhao LL, Schatz GC (2003) The optical properties of metal nanoparticles: the influence of size, shape and dielectric environment. J Phys Chem B 107:668-677 
Kevitec L, Panacek A, Soukupova J, Kolar M, Vecerova R, Prucek R (2008) Effect of surfactants and polymers on stability and antibacterial activity of silver nanoparticles (NPs). J Phys Chem 112(15):5825-5834

Lee HY, Park HK, Lee YM, Kim K, Park SB (2007) A practical procedure for producing silver nanocoated fabric and its antibacterial evaluation for biomedical applications. Chem Commun 2959-2961

Maiti S, Barman G, Konar LJ (2013) Synthesis of silver nanoparticles having different morphologies and its application in estimation of chlorpyrifos. Adv Sci Focus 1:145-150

Morones JR, Elechiguerra JL, Camacho A, Holt K, Kouri JT, Ramirez JT (2005) The bactericidal effect of silver nanoparticles. Nanotechnology 16:2346-2361

Parikh DV, Fink T, Rajasekharan K, Sachinvala ND, Sawhney APS, Calamari TA, Parikh AD (2005) Antimicrobial silver/sodium carboxymethyl cotton dressings for burn wounds. Text Res J 75:134-138

Peng S, Mc Mahon JM, Schatz GC, Gray SK, Sun Y (2010) Reversing the size-dependence of surface plasmon resonances. PNAS 107:14530-14534

Rupp ME, Fitzgerald T, Marion N, Helget V, Puumala S, Anderson JR, Fey PD (2004) Effect of silver-coated urinary catheters: efficacy, cost-effectiveness antimicrobial resistance. Am J Infect Control 32:445-450

Russell AD, Hugo WB (1994) Antimicrobial activity and action of silver. Prog Med Chem 31:351-370

Samuel U, Guggenbichler JP (2004) Prevention of catheter-related infections: the potential of a new nanosilver impregnated catheter. Int J Antimicrob Agents 23:75-78

Silver S, Phung LT (1996) Bacterial heavy metal resistance: new surprises. Annu Rev Microbiol 50:753-789

Singh A, Jain D, Upadhyay MK, Khandlewal N, Verma HN (2010) Green synthesis of silver nanoparticles using Argemone mexicana leaf extract and evaluation of their antimicrobial activities. Dig J Nanomater Bios 5:483-489

Sondi I, Salopek-Sondi B (2004) Silver nanoparticles as antimicrobial agent: a case study on E. coli as a model for Gram-negative bacteria. J Colloid Interface Sci 275:177-182

Stepanov AL (1997) Optical properties of metal nanoparticles synthesized in a polymer by ion implantation: a review. Tech Phys 49:143

Stoimenov PK, Klinger RL, Marchin GL, Klabunde KJ (2000) Metal oxide nanoparticles as bactericidal agents. Langmuir 18:6679-6686

Sun RW, Chen R, Chung NP, Ho CM, Lin CL, Che CM (2005) Silver nanoparticles fabricated in Hepes buffer exhibit cytoprotective activities toward HIV-1 infected cells. Chem Commun 40:5059-5061

Ulkur E, Oncul O, Karagoz H, Yeniz E, Celikoz B (2005) Comparison of silver-coated dressing (Acticoat ${ }^{T}{ }^{T}$ ), chlorhexidine acetate $0.5 \%$ (Bactigrass ${ }^{\circ}$ ), and fusidic acid 2\% (Fucidin") for topical antibacterial effect in methicillin-resistant Staphylococci-contaminated, full-skin thickness rat burn wounds. Burns 31:874-877

Yuranova T, Rincon AG, Bozzi A, Parra S, Pulgarin C, Albers P, Kiwi J (2003) Antibacterial textiles prepared by RF-plasma and vacuum-UV mediated deposition of silver. Photochem Photobiol A 161:27-34

doi:10.1186/s40543-014-0040-3

Cite this article as: Maiti et al:: Antimicrobial activities of silver nanoparticles synthesized from Lycopersicon esculentum extract. Journal of Analytical Science and Technology 2014 5:40

\section{Submit your manuscript to a SpringerOpen ${ }^{\circ}$ journal and benefit from:}

- Convenient online submission

- Rigorous peer review

- Immediate publication on acceptance

- Open access: articles freely available online

- High visibility within the field

- Retaining the copyright to your article

Submit your next manuscript at $>$ springeropen.com 